\title{
A NEW PERSPECTIVE ON BRONCHIAL ASTHMA AND CHRONIC OBSTRUCTIVE PULMONARY DISEASE OVERLAP: POTENTIAL DIAGNOSTIC CRITERIA
}

DOI: 10.36740/WLek202007131

\author{
Tetyana 0. Pertseva, Lyudmyla I. Konopkina, Alina 0. Babenko \\ DNIPROPETROVSK MEDICAL ACADEMY OF MINISTRY OF HEALTH OF UKRAINE, DNIPRO, UKRAINE
}

\begin{abstract}
The aim: The aim of the research was to analyze the results of observation and examination of COPD patients in order to identify a group of individuals with potential asthma overlap. Materials and methods: We have conducted a two-stage dynamic investigation of 43 COPD patients during 3-8 years. The patients were divided into two groups: group 1 counted 30 individuals who presented with at least one episode of reversible bronchial obstruction (RBO) during the observation; group $2-13$ individuals who presented with nonreversible bronchial obstruction (nonRBO). At the first stage, we conducted a clinical observations analysis and studied lung function examination records; at the second stage, we calculated the markers of allergic inflammation.

Results: It was revealed that around 70\% of COPD patients have occasional episodes of RBO. It was established that the level of blood eosinophils in these patients on the whole is rather low even in people with intermittent RBO, and the total IgE level appeared to be significantly higher in patients with intermittent RBO comparing to the level of this marker in patients who have nonRBO.

Conclusions: COPD patients with intermittent RBO and high level of total IgE level form a group with potential asthma overlap.
\end{abstract}

KEY WORDS: COPD, asthma, overlap, allergic airway inflammation, bronchial obstruction

Wiad Lek. 2020;73(7):1480-1483

\section{INTRODUCTION}

In the late $20^{\text {th }}$ - early $21^{\text {st }}$ century, a lot of academic research dealt with different issues related both to asthma [1, $2]$, and to chronic obstructive pulmonary disease (COPD) $[3,4,5]$.

In 2014, after an extensive review of available academic literature, international experts first discussed in GINA and GOLD guidelines the possibility of asthma combination with COPD [6]. Later on, this combination was referred to as ACO, i.e. Asthma-COPD overlap [7]. To date, this topic is being actively discussed seeking to elaborate standards both for diagnosis, and for patient treatment. This includes updating diagnostic criteria for ACO, identifying diagnostic significance of the markers of pathologies combination at different stages of disease course, developing indications for medication administration at certain stages of disease course, specifying medication dose, etc. $[8,9,10]$.

In our opinion, the combination of the two aforementioned diseases may progress in different ways: the first clinical case is a COPD overlap in the course of the existing asthma; the second case is an asthma overlap in the course of the existing COPD.

The first clinical case has been studied in more detail. It is shown that among patients with bronchial asthma, particularly among smokers, there are individuals with predominantly neutrophilic inflammation, rapid decrease in pulmonary ventilation or poorer response to bronchodilator or inhaled glucocorticosteroid (ICS) therapy $[6,7,8]$. It is also believed that the possibility of ACO formation in patients with asthma may be associated with risk factors for constantly progressing airflow limitation, such as childhood asthma, long-term asthma with no ICS intake, first asthma manifestations in adulthood, severe or treatment-resistant asthma $[8,9,10]$. According to the latest findings, ACO formation in patients with previously verified asthma may reach $29 \%$ [9].

The second clinical case is quite rarely discussed in academic literature. Yet, it has been determined that a significant number of patients with COPD may occasionally present with reversible bronchial obstruction (RBO) $[10,11]$, which is more typical of asthma. In COPD, it is mainly explained by bronchial hyperresponsiveness (one of its mechanisms is an expression of a CD38 marker, which catalyzes the formation in smooth muscle cells of cyclic ADP-ribose with further calcium mobilization from intracellular stores [12]) or insufficient or inadequate pharmaceutical treatment [13]. It is also found that, among COPD patients, certain individuals' laboratory test results are more typical of asthma, which is particularly true for high sputum eosinophil count [11]. To date, the mechanisms of connection between clinico-functional and laboratory findings in ACO haven 't been clearly identified; the criteria for unified clinical diagnosis verification have not been determined, either. In view of this, our research focused on this very issue. 


\section{THE AIM}

The aim of the research was to analyze the results of long-term observation and examination of patients with previously verified COPD in order to identify a group of individuals with possible asthma overlap as well as to determine the markers of COPD and asthma combination.

\section{MATERIALS AND METHODS}

The research was carried out in two stages. At the first stage, we analyzed conducted a clinical observations analysis and studied the records of dynamic lung function examination of 43 COPD patients in stable condition only. The observation period made 3-8 years, during which 240 clinic visits were performed (an average number of visits per each patient was $6.5(2.2)$ ). At all visits, the severity of ventilatory failure was determined in all patients via spirometry with the calculation of forced expiratory volume in 1 second $\left(\mathrm{FEV}_{1}\right)$ and forced vital capacity (FVC) in absolute and relative values; the degree of airway obstruction reversibility was determined via bronchodilator testing ( $400 \mathrm{mcg}$ salbutamol delivered by a spacer device). Based on post-bronchodilator $\mathrm{FEV}_{1}$ the patients were referred to groups GOLD II and III.

At the second stage of the research, allergic status markers were identified for all the aforementioned patients: we performed a complete blood count to calculate eosinophil level in absolute value $(\mu \mathrm{L})$ and measured the total serum $\mathrm{IgE}(\mathrm{IU} / \mathrm{ml})$ using the enzyme-linked immunosorbent assay.

The COPD diagnoses were formulated according to the Order of the Ministry of Healthcare of Ukraine № 555 from 27 June 2013. All patients received adequate background therapy depending on the clinical group of the disease and according to international and national guidelines depending on the severity of disease course (long-acting bronchodilators with/without ICS as a routine therapy and short-acting $\beta_{2}$-agonist salbutamol as required).

All patients gave a written consent for retrospective clinical observations analysis and laboratory investigations.

The study was conducted according to Helsinki declaration with the permission of the Bioethical commission Dnipropetrovsk medical academy of the Ministry of Health of Ukraine.

Statistical data processing were performed using the STATISTICA 6.1 software ("StatSoftInc", serial number AGAR909E415822FA). Quantitative data were analyzed after the arithmetic mean and standard deviation at normal markers distribution and after the median and interquartile range [25\%;75\%] (in M (SD) ) at non-normal markers distribution. The type of quantitative data distribution was determined after the Shapiro-Wilk (W) and Kolmogorov-Smirnov (D) criteria; the data were clinically significant at $\mathrm{p}>0.05$. Qualitative characteristics of the markers (elevated/normal) were presented as a number of patients (n) having those markers, and as relative frequencies expressed as a percentage (\%). To compare two independent groups of markers, we used the Mann-Whitney U-test (U) in case of non-normal data distribution. The probability of differences in the relativeindices (of data distribution) was identified via Fisher's exact test; the differences between the groups at $\mathrm{p}<$ 0.05 were considered significant.

\section{RESULTS AND DISCUSSION}

The clinical observations analysis at the end of the first stage of the research showed that male patients were a majority (35 (81.4\%)); an average age at the first clinic visit was 62.0 (7.15); body mass index (BMI) was 27.3 (4.3); all patients had a history of smoking in the past or upon initial examination (a pack-year ratio - 27.8 (4.9)); disease duration - 15.7 (3.9) years.

We noticed that at the initial stages of COPD development, the patients' diagnosis was clear: the patients complained of first clinical signs of the disease at the age $>40$ (at first, they presented primarily with a cough; further on, they developed a shortness of breath, increased cough, sputum containing mucus and pus); the presence of a post-bronchodilator $\mathrm{FEV}_{1} / \mathrm{FVC}<0.70$ was confirmed spirometrically.

At patients observation stages (during each subsequent clinic visit), we controlled both clinical, and spirometrical markers. It was established that a certain part of the patients had developed clinical symptoms variability - at different visits, shortness of breath and cough had different severity, despite the fact that the patients received regular and full-fledged medication therapy. Besides, the same patients appeared to have variable spirometrical markers. At the same time, we encountered with the patients whose clinical symptoms and functional performance remained stable throughout the long-term observation. Following the above mentioned, all examined patients were divided into two groups: group 1 counted 30 (69.8\%) individuals who presented with at least one episode of RBO during the long-term observation (post-bronchodilator FEV, increased by $>12 \%$ and $>200 \mathrm{ml}$ comparing to baseline characteristics; $\mathrm{FEV}_{1}$-increase fluctuation had a wide range of 12.2 to $69 \%$ and of 230 to $910 \mathrm{ml}$ ); group 2 counted 13 $(30.2 \%)$ individuals who presented with nonreversible bronchial obstruction (nonRBO) throughout the whole observation period. The average age in group 1 didn't differ from that in group $2(60.6(7.18)$ and $65.2(6.19)$ years, respectively) (two-tailed Student's t-test: $\mathrm{t}=1.83$; the number of degrees of freedom is $41 ; \mathrm{p}=0.074)$; body mass index (BMI) was similar in both groups (27.5 (4.5) and 26.8 (3.8) $\mathrm{kg} / \mathrm{m}^{2}$, respectively) (two-tailed Student's t-test: $\mathrm{t}=$ 0.46 ; the number of degrees of freedom is $41 ; \mathrm{p}=0.647$ ). Thus, it was demonstrated that around $2 / 3$ of patients with previously verified COPD have occasional episodes of RBO. Obviously, RBO may be associated with a number of factors. However, in order to exclude the possibility of asthma overlap in these patients, the following stage of the research was performed.

At the second stage, it was shown that the identified groups of patients had somewhat different number of individuals with elevated and normal blood eosinophils and/or total IgE (Table 1).

It is noteworthy that, if group 1 presented with elevated eosinophil count a bit more frequently than group 2 (although statistically inaccurate), elevated total $\operatorname{IgE}$ was detected in group 1 in $40 \%$ of cases, while in group 2 it was not detected in any case. Consequently, the eosinophil marker demon- 
Table 1. Patient distribution according to blood eosinophils and total IgE

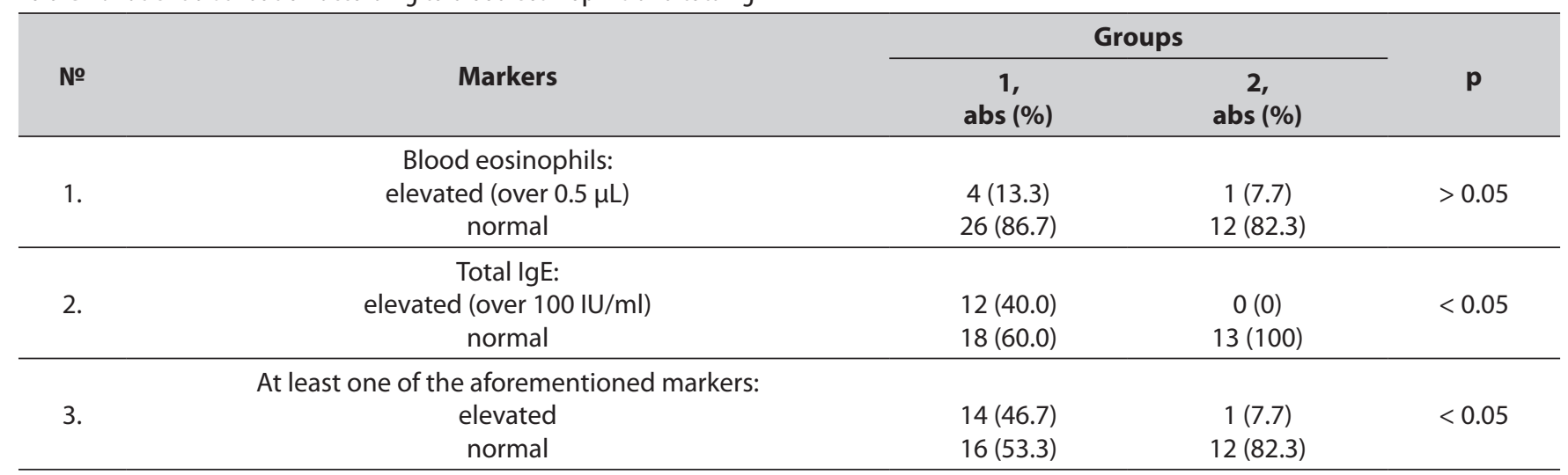

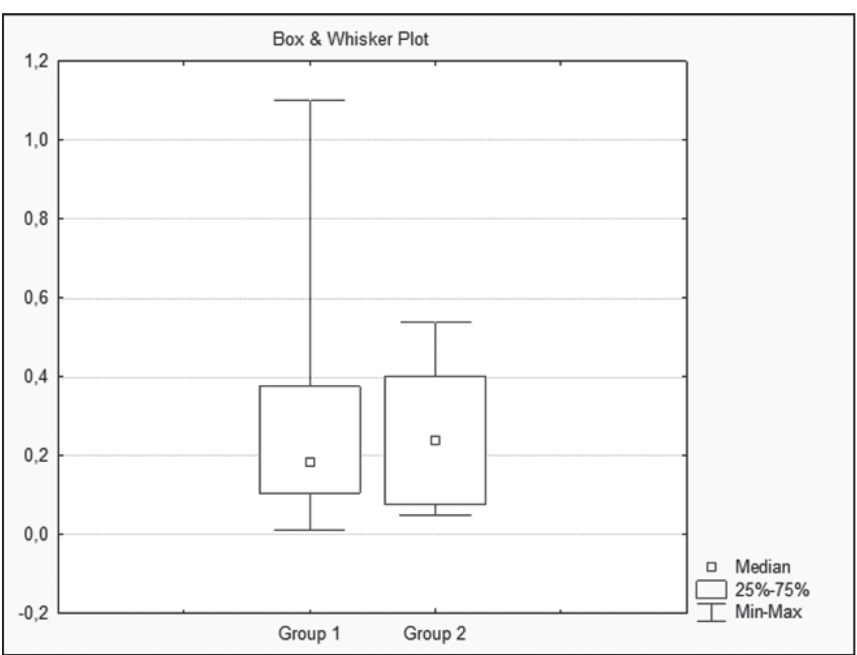

Fig 1. Eosinophils levels in the groups of examined COPD patients

strated a quite low sensitivity as to the identification of the patients' allergic state, since in many of those, at high total IgE, blood eosinophils didn 't exceed the reference values.

The absolute values of allergic state markers in the groups of the examined patients are provided in Fig 1 and 2 .

It was discovered that blood eosinophils in COPD patients in the stable disease phase are in general quite low, and in the majority of individuals $(86.1 \%)$ they do not exceed $0.4 \mu \mathrm{L}$. Besides, this marker in patients with CODP who have intermittent RBO (group 1) doesn 't differ from that in patients who have nonRBO (group 2) $(\mathrm{p}=0.827)$.

Total IgE in COPD patients who have intermittent RBO appeared to be significantly higher than that in patients who have nonRBO ( $\mathrm{p}=0.008)$.

Our findings match the results of other researches, which show that peripheral blood eosinophil count in COPD patients doesn't correlate either with bronchial hyperresponsiveness rate, or with the number of disease exacerbations, and is in general quite low $[13,14,15]$.

Our findings don 't contradict the recent study, which also demonstrates that increased total $\operatorname{IgE}(44 \%)$ is pretty common for COPD patients. The latter may witness to the lower airway allergic inflammation in certain COPD patients even without any clinical manifestations of atopy, and therefore, be a marker of ACO [15].

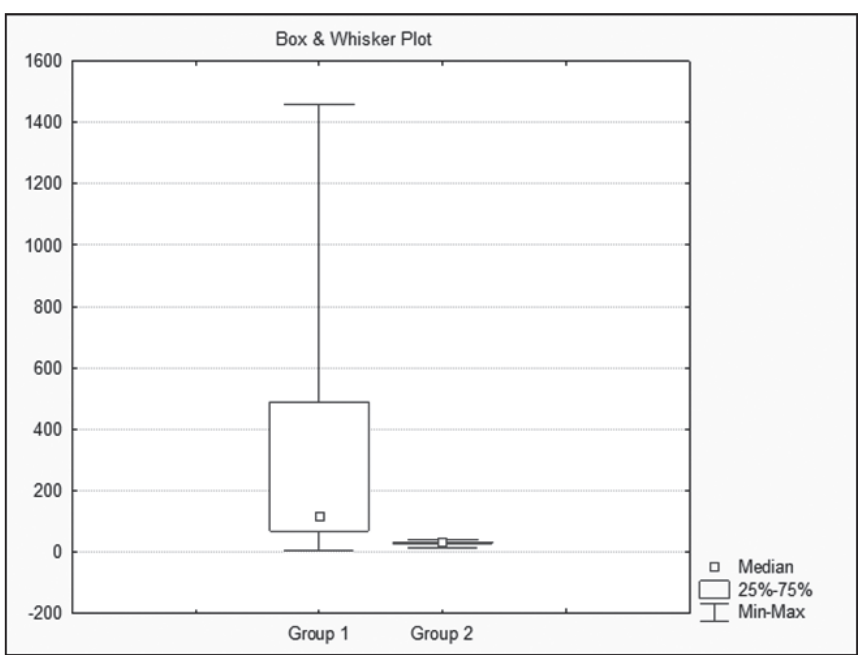

Fig 2. Total lgE in the groups of examined COPD patients

Therefore, our research enabled us to identify a group of COPD patients, whose diagnosis at the initial stages of the disease was clear and characterized by the following typical signs: long-term tobacco smoking, first clinical manifestations of the disease at the age $>40$, gradually increasing shortness of breath and cough with sputum containing mucus and pus, spirometrically confirmed the presence of a post-bronchodilator FEV1/FVC $<0.70$. However, with the diseases development, these patients presented with the signs of a different illness asthma: intermittent RBO, elevated total IgE and sometimes blood eosinophilia. Keeping in mind a stage-like nature of diseases overlap, we recommend referring to such clinical cases as CAO (i.e. COPD-Asthma overlap) instead of ACO. The formation of $\mathrm{CAO}$ may require patient treatment revision and management; particularly, treatment regimen should include high doses of ICS if patients have not taken any before.

\section{CONCLUSIONS}

1. COPD patients require compulsory long-term dynamic observation not only to control clinical and functional performance and medication therapy management (as appropriate), but also to exclude possible asthma overlap with further CAO development and, consequently, to manage treatment strategy. 
2. Blood eosinophilia determination in COPD patients is not recommended for identifying the possibility of $\mathrm{CAO}$ formation due to a low diagnostic sensitivity of this marker.

3. Both dynamic control of RBO and total serum IgE determination (at least occasional) are recommended for verifying $\mathrm{CAO}$ formation in the course of COPD.

4. In case of CAO formation, patient follow-up should lean on diagnostic and treatment standards not only for COPD, but also for bronchial asthma.

\section{REFERENCES}

1. Feshchenko Yu. I., Mostovyi Yu. M., Babiichuk Yu. V. Procedura adaptacii mizhnarodnogo opytuvalnyka ocinky yakosti zhyttia MOS SF-36 v Ukraini. Dosvid zastosuvannia u khvorykh bronkhialnoiu astmoiu [The procedure of adaptation of international quality of life questionnaire MOS SF-36 in Ukraine. The experience of administration in asthma patients]. UkrainianPulmonologyJournal. 2002;3:9-11. (In Ukrainian).

2. Mostovyi Yu. M. Rol bakterialnykh infektsii i vybir antybiotykiv pry infektsiino-zalezhnykh zahostrenniakh bronckialnoi astmy [The role of bacterial infections and choose of the antibiotics in the infectious exacerbations of bronchial asthma]. AsthmaAndAllergy. 2002;2:35-39. (In Ukrainian).

3. Pertseva T. A., Botvinikova L. A., Konopkina L. I. Rol individualnyh reabilitatsionnyh programm $v$ kompleksnom lechenii bolnyh hronicheskim obstruktivnym bronhitom [The role of individual rehabilitation programs in the complex treatment of patients with chronic obstructive bronchitis]. UkrainianPulmonologyJournal. 2004;2:32-34. (In Russian).

4. Pertseva T. 0., Konopkina L. I., Bratus 0. V. Rol kolonizatsii nyzhnikh dykhalnykh shliakhiv bakterialnoiu floroiu u formuvanni khronichnoho systemnoho zapalennia pry khronichnomu obstruktyvnomu zakhvoriuvanni lehen [The role of colonization of the lower respiratory tract in bacterial flora in the formation of chronic systemic inflammation in chronic obstructive pulmonary disease]. MedicniPerspektivi. 2009;14(1):126-131. (In Ukrainian).

5. Pertseva T. O., Konopkina L. I. Osoblyvosti rehionalnoi chutlyvosti respiratornykh patoheniv: optymizatsiia vedennia khvorykh na KhOZL [Features of regional sensitivity of respiratory pathogens: optimization of management of patients with COPD]. MedicniPerspektivi. 2009;14(3):37-45. (In Ukrainian).

6. Global Initiative for Chronic Obstructive Lung Disease (GOLD). Diagnosis of diseases of chronic airflow limitation: asthma, COPD and asthmaCOPD overlap syndrome (ACOS) (updated 2015).doi: https://goldcopd. org/asthma-copd-asthma-copd-overlap-syndrome/

7. Global Initiative for Asthma (GINA). Global strategy for asthma management and prevention (updated 2018). doi: https://ginasthma. org/2018-gina/
8. Cosío B.G., Dacal D., de Llano L.P. Asthma-COPD overlap: identification and optimal treatment. Ther Adv Respir Dis. 2018;12:1-11.

9. de Llano L.P., Cosío B.G., Miravitlles M. et al. Accuracy of a new algorithm to identify asthma-COPD overlap (ACO) patients in a cohort of patients with chronic obstructive airway disease. Arch Bronconeumol. 2018;54(4):198-204.

10. Lee H., Tho N.V., Nakano Y. et al. Asthma-COPD overlap syndrome (ACOS): a diagnostic challenge. Respirology. 2016;16(3):410-418.

11. Muller V., Galffy G., Orosz M. et al. Characteristics of reversible and nonreversible COPD and asthma and COPD overlap syndrome patients: an analysis of salbutamol Easyhaler data. Int J Chron Obstruct Pulmon Dis. 2016;11:93-101.

12. Guedes A., Deshpande D., Dileepan M. et al. CD38 and airway hyperresponsiveness: studies on human airway smooth muscle cells and mouse models. Can J Physiol Pharmacol. 2015;93(2):145-153.

13. Zanini A., Cherubino F., Zampogna E. et al. Bronchial hyperresponsiveness, airway inflammation, and reversibility in patients with chronic obstructive pulmonary disease. Int J Chron Obstruct Pulmon Dis. 2015;10:1155-1161.

14. Cukic V. Blood count of eosinophil polymorphonuclear leucocytes and bronchial hyperreactivity in chronic obstructive pulmonary disease. Medical Archives. 2017;71(5):347-350.

15. Samaha H.M.S., Elsaid A.R., NasrEldin E. Total serum IgE level in COPD patients. Egypt J Chest Dis Tuberc. 2015;64(3):573-577.

\section{ORCID and contributionship:}

Tetyana O. Pertseva: 0000-0001-6998-4974 A,D,E,F

Lyudmyla I. Konopkina: 0000-0002-2238-6501 ${ }^{A, B, C, D, E}$

Alina O. Babenko: 0000-0002-4344-8871 B,C,D

\section{Conflicts of interest:}

Authors declare no conflict of interest.

\section{CORRESPONDING AUTHOR \\ Alina. 0. Babenko}

Dnipropetrovsk Medical Academy of Ministry of Health of Ukraine

13 Batumska st., 49000 Dnipro, Ukraine

tel: +380933078588

e-mail: alinababenk02406@gmail.com

Received: 29.08 .2019

Accepted: 27.04 .2020

A - Work concept and design, B - Data collection and analysis, C - Responsibility for statistical analysis, D-Writing the article, $\mathbf{E}$-Critical review, $\mathbf{F}$-Final approval of the article 